\title{
AKTIIVINEN KANSALAISUUS JÄÄMÄSSÄ EU:SSA RETORIIKAKSI
}

$\mathrm{J}$ os on kansalaisuuden käsitettä hankalaa määritellä, vielä työläämpää on todistaa, mitä oikein tarkoitamme aktiivisella kansalaisuudella Euroopassa tai mitä tarkoitamme kansalaisten Euroopalla. Juhlapuheissa ja julistuksissa ne toki esiintyvät, mutta tiedämme, että ihanteet ja todellisuus eivät kohtaa toisiaan. Euroopan unioni on edelleen maanosansa asukeille etäinen ja vaikeasti ymmärrettävä järjestelmä.

Yleensä ollaan yhtä mieltä siitä, että aktiivisen kansalaisuuden kehittyminen edellyttää oppimista, useimmiten muualla kuin koulun penkillä. EU innostui korostamaan aktiivisen kansalaisuuden tärkeyttä etenkin 1990-luvun puolivälistä lähtien ja alkoi liittää sitä elinikäisen oppimisen strategioihin. Komission muistiossa Elinikäisestä oppimisesta (2000) aktiivinen kansalaisuus kuvattiin jopa yhtä tärkeänä elinikäisen oppimisen tavoitteena kuin työllistettävyyden edistäminen. Samalla linjalla jatkoi komission tiedonanto Eurooppalaisen elinikäisen oppimisen alueen toteuttamisesta (2001), missä em. muistion ajatuksia oli laajan kansalaiskuulemisen pohjalta laadittu konkreettisiksi ehdotuksiksi.

Samaan aikaan eurooppalaisessa koulutusyhteistyössä oli valmisteltu selvitystä Koulutusjärjestelmien konkreettisista tulevaisuuden tavoitteista (2001). Jo käsiteltäessä elinikäisen oppimisen muistiota yllättävän monet tahot - myös Suomessa - karsastivat elinikäisen oppimisen tunnustamista koulujärjestelmien ulkopuolella. Niinpä elinikäisen oppimisen strategiaesitykset haluttiin kytkeä koulutusjärjestelmien tavoitteisiin. Asia vahvistettiin neuvoston päätöslauselmassa Elinikäisestä oppimisesta (2002). Näin Euroopan koulutuksen tulevaisuutta lähdettiin luotaamaan koulutusjärjestelmien tulevaisuuden tavoitteita koskevan työohjelman voimalla, joka oli hyväksytty Barcelonan huippukokouksessa keväällä 2002.

Työohjelma jakaantuu kolmeen strategiseen tavoitteeseen ja yhteensä 13 alatavoitteeseen. Nimensä mukaisesti työohjelma on hyvin järjestelmäkeskeinen. Aktiivisen kansalaisuuden kohtaloksi tuli asettua toisen strategisen tavoitteen, Koulutukseen pääsyn helpottaminen, yhdeksi alatavoitteeksi yhdessä sosiaalisen yhteenkuuluvuuden ja yhtäläisten mahdollisuuksien kanssa.

Myöhemmin komissio nimitti kolmentoista alatavoitteen pohjalta kahdeksan työryhmää, jotka tekevät heinäkuuhun 2003 mennessä alueestaan ehdotuksia. Komissio puolestaan laatii ehdotusten pohjalta neu-

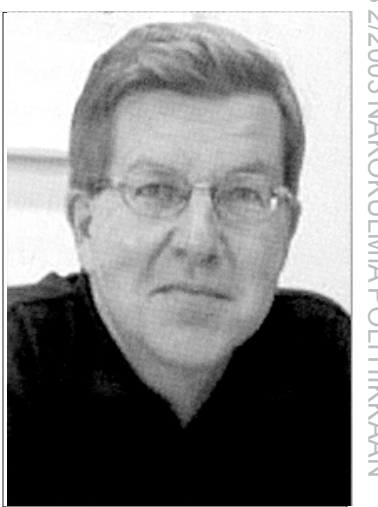

Jorma Turunen vostolle raportin, joka hyväksytään kevään 2004 huippukokouksessa. Yksi työryhmistä työskentelee juuri aktiivisen kansalaisuuden, yhtäläisten mahdollisuuksien ja sosiaalisen yhteenkuuluvuuden kanssa. Kaikki työryhmät ovat suuria, kussakin runsaat 40 jäsentä edustaen lähinnä jäsen- ja hakijamaiden opetushallintoja. Kansalaisuutta käsittelevään työryhmään on päässyt myös muutama eurooppalaisten työmarkkina- ja kansalaisjärjestöjen edustaja.

Aktiivisen kansalaisuuden työryhmä tullee nostamaan esiin kansalaisuushankkeiden hyviä käytäntöjä, esittämään verkostojen sekä tietokantojen perustamista, arviointijärjestelmien kehittämistä tai uusien indikaattoreiden työstämistä. Tähän lienee tyytyminen, koska kaikki tietävät resurssien niukkuuden laajentumisen kynnyksellä.

Onko vielä mahdollista, että eurooppalaisen koulutusyhteistyön tuloksena syntyisi lisää resursseja ja sellaisia välineitä, joilla voitaisiin torjua syrjäytymiskehitystä ja vahvistaa kansalaisyhteiskuntaa? Onnistutaanko eurooppalaisella tasolla koskaan yhdistämään toisaalla elinikäisen oppimisen yhteiskunnalliset ja kulttuuriset tavoitteet ja toisaalla taloudellisen kilpailukyvyn koulutukselle asettamat vaatimukset?

\section{Jorma Turunen}

EAEA:n varapuheenjohtaja 1998-2000 ja puheenjohtaja 2000-2002 